\title{
Modified arrowroot starch and glucomannan for preserving physicochemical properties of sweet bread
}

\section{Amido modificado de araruta e glucomanano na preservação das propriedades físico-químicas de pão doce}

\author{
Damat Damat ${ }^{1}$ (D) Roy Hendroko Setyobudi² ${ }^{*}$ (D) Peeyush Soni ${ }^{3}$ (D) , Anas Tain ${ }^{4}$ (D), \\ Hany Handjani ${ }^{5}$ (D), Uswatun Chasanah ${ }^{6}$
}

\author{
'University of Muhammadiyah Malang, Department of Food Science and Technology, East Java, Indonesia \\ ${ }^{2}$ University of Muhammadiyah Malang, Department of Agriculture Science, East Java, Indonesia \\ ${ }^{3}$ Indian Institute of Technology Kharagpur, Department of Agricultural and Food Engineering, Kharagpur, India \\ ${ }^{4}$ University of Muhammadiyah Malang, Department of Agribusiness, Faculty of Agriculture and Animal Science, East Java, Indonesia \\ ${ }^{5}$ University of Muhammadiyah Malang, Department of Fishery, Faculty of Agriculture and Animal Science, East Java, Indonesia \\ 'University of Muhammadiyah Malang, Department of Pharmacy, Faculty of Health Science, East Java, Indonesia \\ ${ }^{*}$ Corresponding author: damatumm@gmail.com \\ Received in May 29, 2020 and approved in August 31, 2020
}

\begin{abstract}
Sweet bread is associated with smooth texture and high carbohydrate content, tasty and filling - quality that makes it preferred for snack. The key is in formulating raw material and other components. Commonly, sweet bread has short shelf life. Frozen dough could be the solution to this problem, and glucomannan addition during freezing process should be able to improve its physicochemical characteristics. This research aims to determine the effect of adding modified arrowroot (Maranta arundinacea L.) starch (MAS) as substitution, and glucomannan as frozen dough cryoprotectant toward sweet bread's physicochemical. Randomized Complete Block Design Factorial (RCBD) was applied, and two factors were studied. The first factor was modified arrowroot starch $(0.00 \%, 3.75 \%$, and $7.50 \%)$ and the second was glucomannan $(0.0 \%, 0.5 \%$, and $1.0 \%)$. The best result was combination between MAS $3.75 \%$ and glucomannan $0.5 \%$, reaching dough expansion volume range of $50 \%$ to $60 \%$, bread expansion volume range of $77 \%$ to $80 \%$, hardness range of $2 \mathrm{~N} \mathrm{~mm}^{-2}$ to $3 \mathrm{~N} \mathrm{~mm}^{-2}$, elasticity range of $88 \%$ to $96 \%$, moisture content of $16 \%$ to $19 \%$, ash content of $1.4 \%$ to $1.7 \%$, fat content of $10 \%$ to $15 \%$, protein content of $5 \%$, and carbohydrate content of $51 \%$ to $66 \%$. MAS is able to substitute wheat flour in bread production only if it is combined with glucomannan.
\end{abstract}

Index terms: Cryoprotectant; frozen dough; resistant fiber; retrogradation; shelf life.

\section{RESUMO}

O pão doce é caracterizado por apresentar textura macia, alto teor de carboidratos, sabor e recheio agradáveis que o tornam preferido para lanches rápidos. A chave está nas matérias-primas e outros componentes usados na sua formulação. No entanto, o pão doce possui vida de prateleira curta. O congelamento da massa pode ser usado para solucionar esse problema e a adição de glucomanano durante o congelamento pode melhorar suas características físico-químicas. O objetivo dessa pesquisa foi determinar o efeito do uso de amido modificado de araruta (Maranta arundinacea L.) como substituição e glucomanano como crioprotetor das propriedades físico-químicas da massa congelada de pão doce. O delineamento experimental em blocos inteiramente casualizados foi usado em esquema fatorial com dois fatores. O primeiro fator foi a adição do amido modificado de araruta em três níveis (0,00\%, 3,75\% e 7,50\%) e o segundo fator foi o glucomanano em três níveis (0,0\%, 0,5\% e 1,0\%). O melhor resultado foi a combinação de MAS 3,75\% e glucomanano 0,5\%, atingindo volume de expansão da massa de $50 \%$ a $60 \%$, volume de expansão do pão de $77 \%$ a $80 \%$, faixa de dureza $2 \mathrm{~N} \mathrm{~mm}{ }^{-2}$ a $3 \mathrm{~N} \mathrm{~mm}{ }^{-2}$, faixa de elasticidade de $88 \%$ a $96 \%$, teor de água de $16 \%$ a 19\%, teor de cinzas de 1,4\% a 1,7\%, teor de gordura de 10\% a 15\%, teor de proteínas $5 \%$ e teor de carboidratos $51 \%$ a $66 \%$. MAS é capaz de substituir a farinha de trigo na produção de pão apenas se for combinada com glucomanano.

Termos para indexação: Crioprotetor; massa congelada; fibra resistente; retrogradação; vida útil. 


\section{INTRODUCTION}

Equally enjoyable among children and adults, sweet bread is quite a popular nibble. Soft, fluffy quality of freshfrom-the-oven product is irresistible, keeping demands on this foodstuff are at an all-time high. However, it is not uncommon for customers to be let down by how quickly it becomes damaged. Retrogradation is the key issue, since it not only decreases the already-short shelf life due to physiochemical reaction (Seetapan et al., 2015) but also causes loss of humidity which affects the texture and turn sweet bread stale (Luo et al., 2018).

Several studies had been conducted to prevent the problems by employing various attempts: controlling raw material and water proportions (Wang et al., 2016), utilizing wheat flour with high gluten content (Kondakci; Zhang; Zhou, 2015), maintaining homogenous structure in dough through stirring process (Öhgren; Fabregat; Langton, 2016), involving additives, optimizing freezing process and storing condition (Akbarian et al., 2015), applying composite flour made of wheat and cassava (Ortolan et al., 2015), and controlling freezing rate and terminal temperature (Ban et al., 2016).

Frozen dough technology has been around for quite some time since it is beneficial in attempts of cutting down time in both formulation processing and labor intensifying, increasing shelf life, upgrading product quality, and accommodating long-distance distribution (Chen et al., 2012). Although having some weaknesses such as gluten capillaries disintegration and yeast viability decrease that can reduce product's volume and quality (Adams; Ragae; Abdel-aal, 2017) - this technique is applied to several bread production due to aforementioned advantages (Ban et al., 2016). The idea is to expand the technology to tackle existing disadvantages. The most common trouble possibly arise in frozen dough is altered texture and/or taste during freezing and storage process (Maity; Saxena; Raju, 2018). Adding cryoprotectant protects capillaries from crystal formulation during icing and thawing process (Maity; Saxena; Raju, 2018; Seetapan et al., 2015), while involving resistant fibers - like inulin and oat - helps to prevent staleness due to freezing (Adams; Ragaee; Abdel-aal, 2017; Setyobudi et al., 2019).

Arrowroot (Maranta arundinacea L.) contains resistant fiber that ferments in the colon and produces SCFA (Short Chain Fatty Acid) (Damat, 2013) the way inulin and oat do, and modified arrowroot starch has high content of resistant starch (RS) (Damat et al., 2019). Hypothetically, combining cryoprotectant application and modified arrowroot starch utilization should be able to let dough lasts longer. As there have not been any studies on this matter, the effect is unknown. Hence, this paper will analyse the effect of applying glucomannan as cryoprotectant and using modified arrowroot starch altogether towards sweet bread physicochemical.

Besides, it will also be analyzed its potential as a functional sweet bread as a result of increasing levels of resistant starch (RS). Resistant starch in food products can reduce the glycemic index of these products, so that it will reduce postprandial blood sugar levels (Damat, 2013). Foods that contain RS content can be used can be classified as functional foods (Raigond; Ezekiel; Raigond, 2015).

\section{MATERIAL AND METHODS}

Preparations and analyses were made at the Food and Microbiology Laboratories and UMM Bakery of University of Muhammadiyah Malang and carried out from January 2019 to April 2019.

\section{Materials and equipment}

Arrowroot (Maranta arundinacea L.) starch as the role material was obtained from farmers in the regency of Pamekasan in Madura (an island in the province of East Java), Indonesia. Glucomannan was obtained from CV. Nura Jaya, Surabaya, Indonesia. Chemical substances used were $\mathrm{H}_{2} \mathrm{SO}_{4}$, Ethanol, Folin-Ciocalteau, Sodium Potassium Tartrate, $\mathrm{CaCO}_{3}, \mathrm{Cu}_{2} \mathrm{SO}_{4}, \mathrm{H}_{3} \mathrm{BO}_{3}$, and Aquades. Among equipment used were sifter (8-inch DIA $\times 2$ inch $[1$ inch $=2.54 \mathrm{~cm}]$ ), autoclave (model 91925, series B0004136), incubator (Incucell MMM), oven (WTC Binder 7200 type), texture profile analyzer (TPA EZ test model SM-500N-168), and glassware.

\section{Experiment design}

Randomized Complete Block Design Factorial (RCBD) - with tree replications - were employed. The first measure was the concentration of modified arrowroot starch (at $0.00 \%, 3.75 \%$, and $7.50 \%$ ), and the second one was glucomannan $(0.00 \%, 0.50 \%$, and $1.00 \%)$. Analysis of Variance (ANOVA) and Duncan's New Multiple Range Test (DNMRT) were also used.

\section{Research implementation}

\section{Modification of arrowroot starch}

The modification of arrowroot starch was carried out by adopting the method developed by Din, Xiong and Fei (2017). In arrowroot starch modification (MAS) 
forming, gelatinization and retrogradation methods were directed. The water-soluble starch was heated to $70{ }^{\circ} \mathrm{C}$ in aquades $(20 \% \mathrm{~b} / \mathrm{v})$ for $10 \mathrm{~min}$, and then further heated at $121{ }^{\circ} \mathrm{C}$ for $60 \mathrm{~min}$, using an autoclave. Next, this starch suspension was placed at $24{ }^{\circ} \mathrm{C}$ for $1 \mathrm{~h}$. It was subsequently followed by retrogradation for $24 \mathrm{~h}$ at $4{ }^{\circ} \mathrm{C}$ in the refrigerator. Afterward, the arrowroot starch was dried using a cabinet dryer at $50{ }^{\circ} \mathrm{C}$ for $28 \mathrm{~h}$. The final steps were subtilizing and sifting ( $80 \mathrm{mesh})$.

\section{Sweet bread production}

Following is sweet bread production according to Park, Jang and Lim (2016), Wheat flour (100\%; 96.25\%; $92.5 \%)$, MAS $(0 \% ; 3.75 \% ; 7.5 \%)$, sugar $(25 \%)$, yeast $(5 \%)$, eggs $(5 \%)$, skimmed milk $(6 \%)$, bread improver $(0.5 \%)$, glucomannan $(0 \% ; 1 \% ; 1.5 \%)$ and water $(45 \%)$ were mixed using a dough mixer for $10 \mathrm{~min}$. Next, salt $(1.5 \%)$ and butter $(20 \%)$ were interspersed for $20 \mathrm{~min}$ until smooth. This dough was subsequently fermented (proofing) for $15 \mathrm{~min}$ at $20^{\circ} \mathrm{C}$, and then the gas formed in it was pulled out (degassing process) using the roller. Successively, thedough was divided into some parts (50 g each), molded, rested for $10 \mathrm{~min}$ (intermediate proofing), then wrapped in polypropylene and stored for $10 \mathrm{~min}$ at $30^{\circ} \mathrm{C}$. The freezing process conducted was for $7 \mathrm{~d}$, at $-15^{\circ} \mathrm{C}$. It was followed by the thawing process using an incubator for $60 \mathrm{~min}\left(30^{\circ} \mathrm{C}\right)$. The last proofing process involved a proofer for $60 \mathrm{~min}$ (at $40^{\circ} \mathrm{C}$, with relative humidity [RH] $80 \%$ to $85 \%$ ). Finally, the dough was baked using an oven for $20 \min \left(180^{\circ} \mathrm{C}\right)$.

\section{Observed parameters}

The parameters observed during the study cover dough expansion volume, sweet bread expansion volume, proximate composition, and bread structure.

i. To measure resistant starch (RS) (Hidayat et al., 2018). Resistant starch content of the sample was analyzed by spectroscopic methods. The sample was hydrolyzed using pepsin, $\alpha$-amylase enzyme, and amyloglucosidase enzyme. Furthermore, the residue is added with $1 \mathrm{~mL}$ glucose assay kit solution (sigma GAGO-20). The absorbance reading of the sample used a spectrophotometer at a wavelength of $500 \mathrm{~nm}$.

ii. To measure dough expansion volume (Park; Jang; Lim, 2016), the thawed dough was divided into three parts $\left(12 \mathrm{~g}\right.$ each) and fermented $\left(35^{\circ} \mathrm{C}\right)$ for $90 \mathrm{~min}$ at an $\mathrm{RH}$ of $85 \%$ on a mass-cylinder.

iii. To measure sweet bread expansion volume, the loaves were weighed using analytical balance and the volume was recorded using rapeseed displacement method (official AACE International method 10-05-01). Furthermore, the specific volume was calculated by dividing the volume-expanded bread weight with sweet bread weight $\left(\mathrm{cm}^{3} \mathrm{~g}^{-1}\right)$ (Hamed et al., 2015).

iv. To measure bread composition, the sweet bread was analyzed for water content, gravimetric ash, fat, and carbohydrate concentrations (Thangaraj, 2016).

v. To measure bread texture, the sweet bread was assessed on its hardness and elasticity. The means was a texture analyzer (TPA EZ test model SM-500N-168) with cylinder diameter about $20 \mathrm{~mm}$ and depth pressure at $40 \%$ from bread length, and pressure velocity at $1 \mathrm{~mm} \mathrm{~s}^{-1}$. The hardness was recorded in kgf (kilogram-force), and the elasticity was in \% (percentage) (Park; Jang; Lim, 2016).

vi. To measure the swelling power and water water solubility, the sample is dispersed into distilled water $(1: 50 \mathrm{w} / \mathrm{v})$ to form a suspension. The suspension $\mathrm{w}$ as then incubated using a water bath at $95{ }^{\circ} \mathrm{C}$ for $30 \mathrm{~min}$. Subsequently cooled at room temperature, and then centrifuged. The swelling power and the water solubility is calculated using the following Equation 1 and 2, (Astuti et al., 2018):

$\mathrm{SP}=[($ weight of precipitate - weight of dry sample) / weight of dry sample] x $100 \%$

$\mathrm{WS}=$ (weight of dry solids in supernatant / weight of dry sample) $\times 100 \%$

vii. To measure oil holding capacity $(\mathrm{OHC})$ and water holding capacity (WHC), the samples were stirred with cooking oil or distilled water $(1: 10 \mathrm{w} / \mathrm{v})$ for $1 \mathrm{~min}$ and then centrifuged for $30 \mathrm{~min}$. $\mathrm{OHC}$ and $\mathrm{WHC}$ are calculated using the Equation 3, (Astuti et al., 2018):

$\mathrm{WHC}$ or $\mathrm{OHC}=[($ weight of wet precipitate - weight of dry sample) / weight of dry sample] x $100 \%$

\section{Statistical analysis}

The data were analyzed using Analysis of Variance (ANOVA) and were examined based on Duncan's New Multiple Range Test (DNMRT) with a rate of significance of $5 \%$.

\section{RESULTS AND DISCUSSION}

\section{Arrowroot starch characteristics}

The comparison between natural and modified arrowroot starch is shown in Table 1. MAS's swelling power is proven higher than the natural one. The heating 
process using high-temperature water has caused strong vibration on the arrowroot molecules, consequently stopped hydrogen bonding. It allows the bonding process between water molecules and hydroxyl group in both amylose and amylopectin, increasing the starch granule volume as the result (Nogueira; Fakhouri; Oliveira, 2018).

Table 1: The natural and modified arrowroot starch characteristics.

\begin{tabular}{ccc}
\hline Parameter & Natural & MAS \\
\hline Swelling power (\%) & 9.54 & 16.28 \\
Solubility (\%) & 4.00 & 8.38 \\
Oil holding capacity (OHC) (\%) & 178 & 180 \\
Water holding capacity (WHC) (\%) & 134 & 301 \\
Resistant starch (\%) & 2.12 & 16.71 \\
\hline
\end{tabular}

MAS also has higher solubility elevation than its natural form. It must be the effect of microstructural surface alteration, which enhances water absorption and component solubility (Hu et al., 2018). The solubility rate is also related to the presence of soluble amylose as starch component that was released and diffused from the starch granules during the swelling process (Zavareze; Dias, 2011). Previous study about potato starch showed that superheated steam at any temperature (between $100^{\circ} \mathrm{C}$ to $160^{\circ} \mathrm{C}$ ) increased molecule mobility, affecting solubility decline in modified potato starch due to additional bindings among amylose-amylose and amylose-amylopectin interaction (Marta; Tensiska, 2017). Based on Table 1, it is known that modified arrowroot starch has a higher content of resistant starch when compared to the content of resistant starch in natural arrowroot starch. According to Hidayat et al. (2018), starch modification by gelatinizationretrogradation can increase levels of resistant starch.

\section{Dough expansion volume}

The result indicates that the interaction between MAS and glucomannan postulated fluctuating dough expansion volumes (Table 2). Dough expansion relies on the presence of polysaccharide - containing amylose and amylopectin - in wheat flour's gluten, and constant addition of MAS lead to a decline in its volume. An optimum process capable of creating better gluten structure is required to increase its extensibility and elasticity. Adding water also helps to establish the perfect viscoelasticity. Well-formed gluten is essential in the fermentation process, since it detains $\mathrm{CO}_{2}$ in the dough under its elastic surface and is therefore able to maintain the optimum expansion volume (Srirejeki et al., 2018). MAS, apparently, could not fully replace wheat flour's role in dough production.

Glucomannan is a hydrocolloid that supports the stability of arrowroot-based product during freezethawing process due to its ability to minimize negative effects appearing in frozen dough. The incorporation of glucomannan as a cryoprotectant has also contributed in the dough expansion volume similar to previous studies (Ortolan et al., 2015). It was due to the total available glucose elevation and the presence of cryoprotectant on the yeast cell effect that allowed starch and hydrocolloid to interact and create complex polymer structure actively assisting the expanding process. Hydrocolloid addition in bread products was aimed to increase the dough storage stability by elevating humidity rate, decreasing bad smell that may form, and triggering structural changes in the dough's main components. However, it affected the physical and thermal aspects of starch and dough, such as gelatinization, retrogradation, fragmentation, and melting rate (Maity; Saxena; Raju, 2018).

\section{Sweet bread expansion volume}

The result indicates that sweet bread expansion volume were varied within $7 \mathrm{~d}$ (Table 3 ). The increase of MAS concentration resulted in the decline of expansion volume. This was, again, due to the lack of amylose and amylopectin - which could not retain as much $\mathrm{CO}_{2}$ in the dough as wheat flour - as the main starch components. There must be a lot of $\mathrm{CO}_{2}$ released during the heating process. It is also consistent with the previous studies - such as the addition of finger millet flour (Devani et al., 2016) and gluten-free flour (as in corn and rice flour) (Ballolli et al., 2014; Messia et al., 2016) - stating that the bread expansion volumes declined due to the treatment. The decrease of sweet bread expansion volumes were caused by soluble starch originated from gluten-free arrowroot starch. Conversely, wheat-based flour has significant impact on elasticity and surface making during the baking process (Devani et al., 2016), while MAS reduces $\mathrm{CO}_{2}$ formation during fermentation.

\section{Sweet bread texture}

The texture of sweet bread became less smooth due to the addition of MAS (Table 4). Since it contained smaller amount of gluten due to less wheat flour involved, there was not enough water trapped in the dough. 
Table 2: Power to expand sweet bread dough.

\begin{tabular}{cccccc}
\hline \multirow{2}{*}{ MAS (\%) } & Glucomannan (\%) & \multicolumn{5}{c}{ Power to expand sweet bread dough on day to: } \\
\cline { 3 - 6 } & & 0 & 2 & 5 & 7 \\
\hline 0.00 & 0.00 & $11.73 \mathrm{bo}$ & $63.02 \mathrm{c}$ & $57.39 \mathrm{~d}$ & $63.53 \mathrm{e}$ \\
0.00 & 0.50 & $10.67 \mathrm{bo}$ & $66.90 \mathrm{~d}$ & $58.43 \mathrm{de}$ & $51.85 \mathrm{~d}$ \\
0.00 & 1.00 & $12.64 \mathrm{bc}$ & $52.92 \mathrm{~b}$ & $61.26 \mathrm{e}$ & $77.55 \mathrm{f}$ \\
3.75 & 0.00 & $11.90 \mathrm{bc}$ & $62.92 \mathrm{c}$ & $58.97 \mathrm{de}$ & $51.94 \mathrm{~d}$ \\
3.75 & 0.50 & $12.28 \mathrm{bc}$ & $64.30 \mathrm{c}$ & $71.09 \mathrm{f}$ & $50.75 \mathrm{c}$ \\
3.75 & 1.00 & $13.26 \mathrm{bc}$ & $74.52 \mathrm{e}$ & $71.90 \mathrm{f}$ & $51.97 \mathrm{~d}$ \\
7.50 & 0.00 & $8.87 \mathrm{a}$ & $48.98 \mathrm{~b}$ & $49.38 \mathrm{c}$ & $43.22 \mathrm{~b}$ \\
7.50 & 0.50 & $8.36 \mathrm{a}$ & $42.07 \mathrm{a}$ & $38.77 \mathrm{a}$ & $42.87 \mathrm{~b}$ \\
7.50 & 1.00 & $8.36 \mathrm{a}$ & $42.29 \mathrm{a}$ & $42.16 \mathrm{~b}$ & $41.50 \mathrm{a}$ \\
\hline
\end{tabular}

Note: Numbers in the same column followed by different alphabetic letters show significant differences based on the DMRT $a=5 \%$.

Table 3: Sweet bread expansion volumes.

\begin{tabular}{cccccc}
\hline \multirow{2}{*}{ MAS (\%) } & Glucomannan (\%) & \multicolumn{4}{c}{ Power to expand sweet bread on day to: } \\
\cline { 3 - 5 } & & 0 & 2 & 5 & 7 \\
\hline 0.00 & 0.00 & $14.97 \mathrm{bc}$ & $84.68 \mathrm{e}$ & $76.43 \mathrm{~d}$ & $78.34 \mathrm{bc}$ \\
0.00 & 0.50 & $14.72 \mathrm{~b}$ & $84.01 \mathrm{e}$ & $82.45 \mathrm{~d}$ & $72.62 \mathrm{~b}$ \\
0.00 & 1.00 & $16.18 \mathrm{c}$ & $72.65 \mathrm{c}$ & $80.41 \mathrm{~d}$ & $84.55 \mathrm{c}$ \\
3.75 & 0.00 & $14.34 \mathrm{~b}$ & $78.81 \mathrm{~d}$ & $78.99 \mathrm{~d}$ & $64.72 \mathrm{~b}$ \\
3.75 & 0.50 & $15.77 \mathrm{c}$ & $77.34 \mathrm{~d}$ & $84.66 \mathrm{~d}$ & $74.04 \mathrm{~b}$ \\
3.75 & 1.00 & $15.67 \mathrm{c}$ & $83.68 \mathrm{e}$ & $75.62 \mathrm{~d}$ & $67.55 \mathrm{~b}$ \\
7.50 & 0.00 & $11.00 \mathrm{a}$ & $61.12 \mathrm{~b}$ & $54.13 \mathrm{~b}$ & $54.17 \mathrm{ab}$ \\
7.50 & 0.50 & $10.56 \mathrm{a}$ & $63.25 \mathrm{~b}$ & $63.51 \mathrm{c}$ & $47.88 \mathrm{a}$ \\
7.50 & 1.00 & $10.40 \mathrm{a}$ & $55.80 \mathrm{a}$ & $50.92 \mathrm{a}$ & $51.09 \mathrm{a}$ \\
\hline Note: Numbers in the same column followed by different alphabetic letters show significant differences based on the DMRT $\mathrm{a}=5 \%$.
\end{tabular}

Table 4: Sweet bread texture levels.

\begin{tabular}{cccccc}
\hline \multirow{2}{*}{ MAS (\%) } & \multirow{2}{*}{ Glucomannan (\%) } & \multicolumn{5}{c}{ Texture $\left(\mathrm{N} \mathrm{mm}^{-2}\right)$} \\
\cline { 2 - 6 } & & 0 & 2 & 5 & 7 \\
\hline 0.00 & 0.00 & $0.92 \mathrm{e}$ & $1.67 \mathrm{a}$ & $5.29 \mathrm{~d}$ & $4.42 \mathrm{c}$ \\
0.00 & 0.50 & $0.96 \mathrm{e}$ & $3.32 \mathrm{c}$ & $4.73 \mathrm{c}$ & $4.56 \mathrm{c}$ \\
0.00 & 1.00 & $0.43 \mathrm{a}$ & $1.44 \mathrm{a}$ & $2.21 \mathrm{a}$ & $2.27 \mathrm{a}$ \\
3.75 & 0.00 & $0.71 \mathrm{~d}$ & $2.84 \mathrm{~b}$ & $3.24 \mathrm{~b}$ & $4.32 \mathrm{c}$ \\
3.75 & 0.50 & $0.59 \mathrm{c}$ & $3.00 \mathrm{c}$ & $3.29 \mathrm{~b}$ & $2.62 \mathrm{a}$ \\
3.75 & 1.00 & $0.47 \mathrm{a}$ & $1.70 \mathrm{a}$ & $2.35 \mathrm{a}$ & $3.62 \mathrm{~b}$ \\
7.50 & 0.00 & $1.51 \mathrm{f}$ & $5.56 \mathrm{~d}$ & $7.34 \mathrm{f}$ & $10.35 \mathrm{~d}$ \\
7.50 & 0.50 & $1.60 \mathrm{f}$ & $5.49 \mathrm{~d}$ & $6.30 \mathrm{e}$ & $10.53 \mathrm{~d}$ \\
7.50 & 1.00 & $1.73 \mathrm{~g}$ & $7.23 \mathrm{e}$ & $7.31 \mathrm{f}$ & $10.64 \mathrm{~d}$ \\
\hline
\end{tabular}

Note: Numbers in the same column followed by different alphabetic letters show significant differences based on the DMRT $a=5 \%$. 
Arrowroot starch contains amylose which is quite high, which is around $24.64 \%$ (Faridah et al., 2014), which further affects the ability of water binding, and it prevents the dough from being elastic.

Glucomannan as a cryoprotectant was one of the hydrocolloids composing acetyl structures that act as water catcher, which affected the pores of crumb and bread structure.

\section{Sweet bread elasticity}

The addition of MAS significantly affected the elasticity of sweet bread (Table 5) as fluctuating values were recorded during the $7 \mathrm{~d}$. Meanwhile, educed elasticity was affected by the addition of MAS, which augmented bread hardness due to the gelatinization process. MAS covered the sweet bread pores. It was also present among gluten layers of wheat flour. Conversely, the substitution process also increased the dough volume and reduced the pores size after fermentation.

The presence of gluten was needed to provide high elasticity, and cryoprotectant was also vital to prevent protein damage. Sweet bread production requires high protein wheat flour, containing intra disulfides and inter polypeptides bound among gliadin and glutenin sub-unit. This binding process should be able to create stable protein conformation. Glutenin could establish disulfide intra polypeptide that contributes to the high elasticity, since it can easily expand and provide high binding capacity with other molecules ( $\mathrm{Lu}$ et al., 2017).

\section{Sweet bread's crumb appearance}

The crumb appearances of sweet bread analyzed are presented (Figure 1a to Figure 1i). The addition of arrowroot starch $(0 \%$ and $7.5 \%)$ has significantly impacted to sweet bread crumb formation process, while MAS 3.75\% addition has not changed it much. Smooth crumb development depended on gluten quality, yeast activity, and modified arrowroot starch substitution, while cryoprotectants saved protein (gluten) and yeast from damage during the freezing process. When yeast released $\mathrm{CO}_{2}$, gluten enhanced elasticity to allow expanding properties of the dough during the fermentation process. As a result, the crumb appearance looked identical. Conversely, glucomannan also protects proteins from bigger pores crumb occurrence throughout the thawing process. Cryoprotectant should inhibit protein denaturation during freezing and storage period (Elliott; Wang; Fuller, 2017). It should also inactivate condensation through hydrogen water bonds creation. Additionally, cryoprotectant increased water's ability as binding agent, preventing water molecule substitution to protein, and stabilizing protein (Elliott; Wang; Fuller, 2017).

\section{Sweet bread's proximate}

The combination of MAS and cryprotectant influenced the water content alteration of sweet bread (Table 6). It was due to its capability to bind water and to inactivate condensation process by creating water bond via hydrogen. Higher water concentration in sweet bread was also obtainable due to larger amount of arrowroot starch assisting water absorption and binding processes.

Alleviation of MAS substitute and cryoprotectant increased the ash contents. Ash attributes to color stabilization, giving lighter hues to the crumbs. Hence, the usage of cryoprotectant could decrease the browning process on sweet bread's surface during baking period (Maity; Saxena; Raju, 2018).

Table 5: Sweet bread elasticity levels.

\begin{tabular}{cccccc}
\hline \multirow{2}{*}{ MAS (\%) } & Glucomannan (\%) & \multicolumn{5}{c}{ Elasticity } \\
\cline { 3 - 5 } & & 0 & 2 & 5 & 7 \\
\hline 0.00 & 0.00 & $17.56 \mathrm{~b}$ & $86.89 \mathrm{a}$ & $88.46 \mathrm{~b}$ & $88.58 \mathrm{~b}$ \\
0.00 & 0.50 & $17.51 \mathrm{~b}$ & $92.00 \mathrm{~b}$ & $86.62 \mathrm{a}$ & $88.08 \mathrm{~b}$ \\
0.00 & 1.00 & $17.62 \mathrm{~b}$ & $90.48 \mathrm{~b}$ & $94.95 \mathrm{c}$ & $95.48 \mathrm{e}$ \\
3.75 & 0.00 & $17.67 \mathrm{bc}$ & $96.47 \mathrm{~d}$ & $87.20 \mathrm{ab}$ & $88.28 \mathrm{~b}$ \\
3.75 & 0.50 & $18.30 \mathrm{c}$ & $92.94 \mathrm{bc}$ & $96.30 \mathrm{~d}$ & $91.95 \mathrm{c}$ \\
3.75 & 1.00 & $18.79 \mathrm{c}$ & $94.01 \mathrm{c}$ & $94.55 \mathrm{c}$ & $94.38 \mathrm{~d}$ \\
7.50 & 0.00 & $16.86 \mathrm{ab}$ & $87.28 \mathrm{a}$ & $87.08 \mathrm{a}$ & $75.21 \mathrm{a}$ \\
7.50 & 0.50 & $16.73 \mathrm{a}$ & $86.00 \mathrm{a}$ & $88.37 \mathrm{~b}$ & $74.54 \mathrm{a}$ \\
7.50 & 1.00 & $16.19 \mathrm{a}$ & $87.53 \mathrm{a}$ & $86.31 \mathrm{a}$ & $73.68 \mathrm{a}$ \\
\hline
\end{tabular}

Note: Numbers in the same column followed by different alphabetic letters show significant differences based on the DMRT a $=5 \%$. 

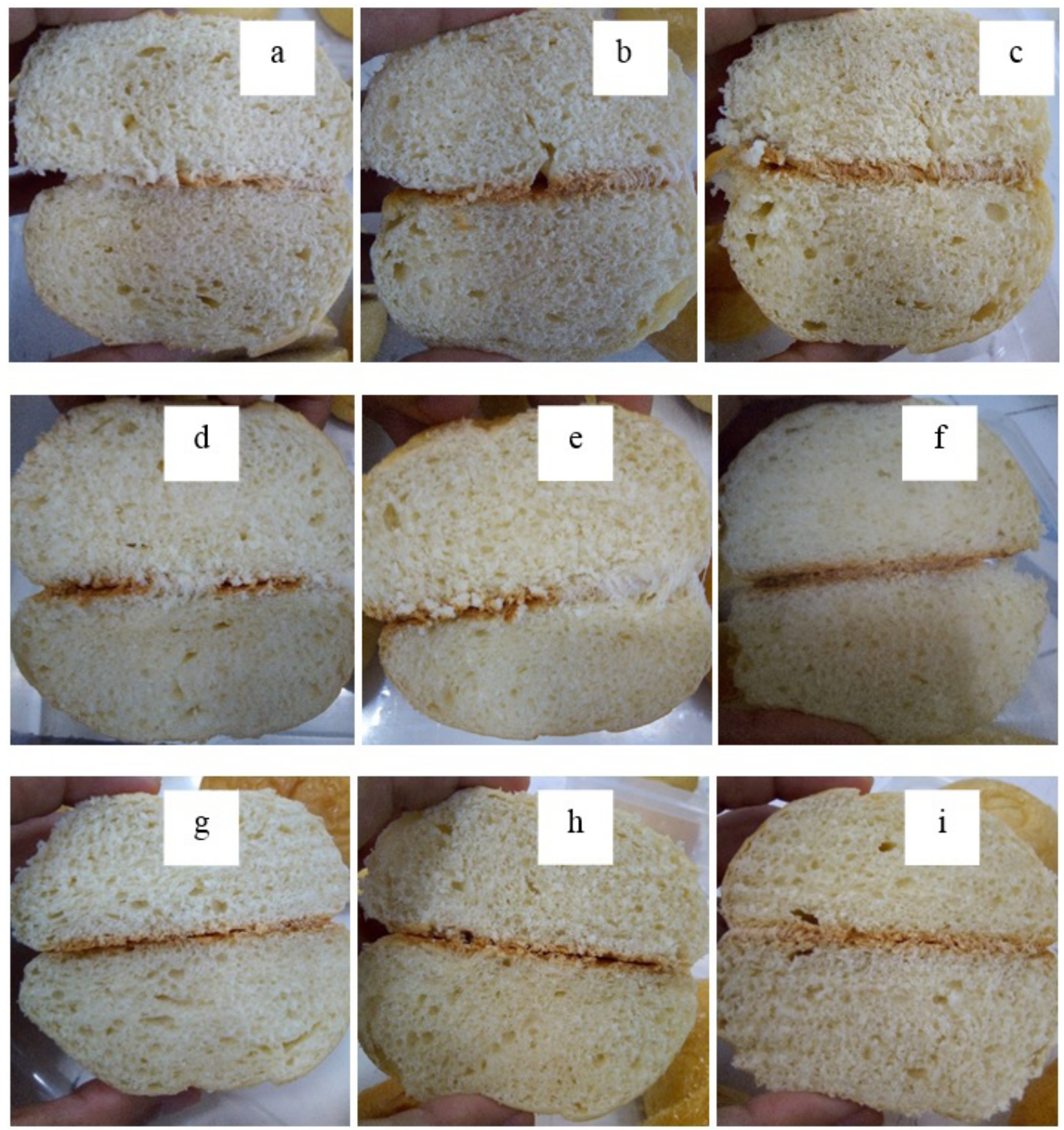

Figure 1: Sweet bread crumb appearances with MAS and glucomannan (a) 0\%:0\%; (b) 0\%:0.5\%; (c) 0\%:1\%; (d) 3.75\%:0\%; (e) 3.75\%:0.5\%; (f) 3.75\%:1\%; (g) 7.5\%:0\%; (h) 7.5\%:0.5\%; (i) 7.5\%:1\%.

Fat concentration relies on water and non-polar material bond. During the frozen dough storing process, the continuously increasing fat concentration was observed. This was due to cryoprotectant containing glucomannan that secured the dough. Furthermore, lipids can form complex compounds with starch and protein (Ortolan et al., 2015), thus increasing the protein content in bread. 
Tabel 6: Sweet bread proximate properties.

\begin{tabular}{ccccccc}
\hline MAS (\%) & Glucomannan (\%) & Water (\%) & Ash (\%) & Lipid (\%) & Protein (\%) & Carbohydrate (\%) \\
\hline 0.00 & 0.00 & $19.79 \mathrm{~d}$ & $1.20 \mathrm{a}$ & $13.70 \mathrm{e}$ & $6.04 \mathrm{bc}$ & $59.27 \mathrm{a}$ \\
0.00 & 0.50 & $20.67 \mathrm{e}$ & $1.660 \mathrm{~b}$ & $10.06 \mathrm{c}$ & $6.84 \mathrm{c}$ & $60.77 \mathrm{a}$ \\
0.00 & 1.00 & $21.43 \mathrm{f}$ & $1.67 \mathrm{~b}$ & $10.40 \mathrm{~d}$ & $6.02 \mathrm{~b}$ & $60.48 \mathrm{a}$ \\
3.75 & 0.00 & $18.04 \mathrm{c}$ & $1.78 \mathrm{~b}$ & $10.51 \mathrm{~d}$ & $5.61 \mathrm{~b}$ & $64.06 \mathrm{a}$ \\
3.75 & 0.50 & $16.53 \mathrm{~b}$ & $1.55 \mathrm{~b}$ & $15.17 \mathrm{f}$ & $5.45 \mathrm{~b}$ & $61.30 \mathrm{ab}$ \\
3.75 & 1.00 & $15.77 \mathrm{a}$ & $1.66 \mathrm{~b}$ & $17.26 \mathrm{f}$ & $5.52 \mathrm{~b}$ & $59.79 \mathrm{a}$ \\
7.50 & 0.00 & $15.29 \mathrm{a}$ & $1.21 \mathrm{a}$ & $4.40 \mathrm{a}$ & $4.78 \mathrm{ab}$ & $74.32 \mathrm{~d}$ \\
7.50 & 0.50 & $16.51 \mathrm{~b}$ & $1.64 \mathrm{~b}$ & $9.31 \mathrm{~b}$ & $4.32 \mathrm{a}$ & $68.22 \mathrm{c}$ \\
7.50 & 1.00 & $15.46 \mathrm{a}$ & $1.64 \mathrm{~b}$ & $9.73 \mathrm{~b}$ & $4.20 \mathrm{a}$ & $68.97 \mathrm{c}$ \\
\hline
\end{tabular}

Note: Numbers in the same column followed by different alphabetic letters show significant differences based on the DMRT $a=5 \%$.

High MAS substitution can reduce protein content, because the protein content of arrowroot starch is quite low, only $0.24 \%$ (Faridah et al., 2014), while the use of cryoprotectant $(0.5 \%)$ has supported the highest protein production in sweet bread. Furthermore, cryoprotectant maintains the amount of protein in dough inhibiting denaturation during freezing and storage processes, resulting in stable maintenance of total protein availability as well as intensification of water bond in bread (Maity; Saxena; Raju, 2018).

The concentration of carbohydrate has increased due to the substitution of MAS and addition of glucomannan. This is due to the high carbohydrate content in arrowroot starch, which is $98.74 \%$ (Faridah et al., 2014). MAS contains amylose and amylopectin as the main components - both considered as a polysaccharide (carbohydrate) - while glucomannan contains heteropolymer and mannose.

\section{CONCLUSIONS}

MAS is able to substitute wheat flour in bread production only if it is combined with glucomannan. The best result obtained is by applying 3.75\% MAS, supported with glucomannan $(0.5 \%)$. The physical properties cover dough expansion volume of $50 \%$ to $60 \%$, sweet bread expansion volume of $77 \%$ to $80 \%$, hardness level of $2.2 \mathrm{~N} \mathrm{~mm}^{-2}$ to $2.9 \mathrm{~N} \mathrm{~mm}^{-2}$, and elasticity of $88 \%$ to $95 \%$. Meanwhile, the chemical properties cover the appearance of homogenous crumb pores as well as water, ash, fat, protein, and carbohydrate contents of $16 \%$ to $19 \%, 1.4 \%$ to $1.7 \%, 10 \%$ to $15 \%, 5 \%$, and $51 \%$ to $66 \%$ respectively.

\section{ACKNOWLEDGMENTS}

The authors wish to thank the Ministry of Research and Technology of the Republic of Indonesia (Grant Number: 119/SP2H/LT/MULTI/L7L2019) for funding this research.

\section{REFERENCES}

ADAMS, V.; RAGAEE, S. M.; ABDELAAL, E. S. M. Rheological properties and bread quality of frozen yeast-dough with added wheat to. Journal of the Science of Food and Agriculture, 97:191-198, 2017.

AKBARIAN, M. et al. Hydrocolloids and cryoprotectant used in frozen dough and effect of freezing on yeast survival and dough structure: A review. International Journal of Life Sciences, 9:1-7, 2015.

ASTUTI, R. M. et al. Effect of physical modification on granule morphology, pasting behavior, and functional properties of arrowroot (Marantha arundinacea L) starch, Food Hydrocolloids, 81:23-30, 2018.

BALLOLLI, U. et al. Development and quality evaluation of foxtail millet [Setaria italica (L.)] incorporated breads. The Journal of Agricultural Science, 27(1):52-55, 2014.

BAN, C. et al. Effects of freezing rate and terminal freezing temperature on frozen croissant dough quality. LWT- Food Science and Technology, 73:219-225, 2016.

CHEN, G. et al. Formation and distribution of ice upon freezing of different formulations of wheat bread. Journal of Cereal Science, 55:279-284, 2012. 
DAMAT, D. et al. Dietary fiber and antioxidant activity of glutenfree cookies with coffee cherry flour addition. Coffee Science, 14(4):493-500, 2019.

DAMAT, D. Effect of butyrylated arrowroot starch to the digesta profile and molar ratio SCFA. Journal of Food Research, 2(2):44-49, 2013.

DEVANI, B. M. et al. Study on quality of white bread enriched with finger millet flour. International Journal of Agriculture, Environment and Bioresearch, 9(5):903907, 2016.

DIN, Z. UD.; XIONG, H.; FEI, P. Physical and chemical modification of starches: A review. Critical Reviews in Food Science and Nutrition, 57(12):2691-2705, 2017.

ELLIOTT, G. D.; WANG, S.; FULLER B. J. Cryoprotectants: A review of the actions and applications of cryoprotective solutes that modulate cell recovery from ultra-low temperatures. Cryobiology, 76:74-91, 2017.

FARIDAH, D. N. et al. Physicochemical characterisation of arrowroot starch (Maranta arundinaceae). Agritech, 34(1):14-21, 2014.

HAMED, A. et al. Quality of bread and cookie baked from frozen dough and batter containing $\beta$-Glucan-rich barley flour fraction. Journal of Food Quality, 385(5):316-327, 2015.

HIDAYAT, B. et al. Application of autoclaving-cooling cycling treatment to improve resistant starch content of cornbased rice analogues. Journal of Physics: Conference Series, 953:1-7, 2018.

$\mathrm{HU}$, X. et al. Modification of potato starch by using superheated steam. Carbohydrate Polymer, 198:375-384, 2018.

KONDAKCI, T.; ZHANG, J. W.; ZHOU, W. Impact of flour protein content and freezing conditions on the quality of frozen dough and corresponding steamed bread. Food and Bioprocess Technology, 8:1877-1889, 2015.

LU, Y. et al. Optimization of a cryoprotective medium to increase the viability of freeze-dried Streptococcus thermophilus by response surface methodology. LWT- Food Science and Technology, 80:92-97, 2017.

LUO, W. et al. Improving freeze tolerance of yeast and dough properties for enhancing frozen dough quality - A review of effective methods. Trends in Food Science and Technology, 72:25-33, 2018.

MAITY, T.; SAXENA, A.; RAJU, P. S. Use of hydrocolloids as cryoprotectant for frozen foods. Critical Reviews in Food Science and Nutrition, 58:420-435, 2018.
MARTA, H.; TENSISKA, T. Functional and amylographic properties of physically-modified sweet potato starch. In: ICSAFS Conference Proceedings. KnE Life Sciences, 2:689-700, 2017.

MESSIA, M. C. et al. Effects of pre-fermented wheat bran on dough and bread characteristics. Journal of Cereal Science, 69:138-144, 2016.

NOGUEIRA, G. F.; FAKHOURI, F. M.; DE OLIVEIRA, R. A. Extraction and characterization of arrowroot (Maranta arundinaceae L.) starch and its application in edible films. Carbohydrate Polymers, 186:64-72, 2018.

ÖHGREN, C.; FABREGAT, N.; LANGTON, M. Quality of bread baked from frozen dough-effects of rye, and sugar content, kneading time and proofing profile. LWT- Food Science and Technology, 68:626-633, 2016.

ORTOLAN, F. et al. Effect of extruded wheat flour and pre-gelatinized cassava starch on process and quality parameters of french-type bread elaborated from frozen dough. Food Research International, 76:402-409, 2015.

PARK, E. Y.; JANG, S. B.; LIM, S. T. Effect of fructo-oligosaccharide and isomalto-oligosaccharide addition on baking quality of frozen dough. Food Chemistry, 213:157-162, 2016.

RAIGOND, P.; EZEKIEL, R.; RAIGOND, B. Resistant starch in food: A review. Journal of the Science of Food and Agriculture, 95(10):1968-1978, 2015.

SEETAPAN, N. et al. Effect of cryogenic freezing on textural properties and microstructure of rice flour/tapioca starch blend gel. Journal of Food Engineering, 151:51-59, 2015.

SETYOBUDI, R. H. et al. Prospect of Fe non-heme on coffee flour made from solid coffee waste: Mini review. IOP Conference Series: Earth and Environmental Science, 293(012035):25, 2019.

SRIREJEKI, S. et al. The effect of water volume and mixing time on physical properties of bread made from modified cassava starch-wheat composite flour. Journal of Physics: Conference Series, 333(1012072):1-6, 2018.

THANGARAJ, P. Proximate composition analysis. In: THANGARAJ, $P$ (Ed.). Pharmacological assays of plant-based natural products. Progress in Drug Research, v.71, Geneva, Switzerland: Springer, p.21-31, 2016.

WANG, P. et al. The contribution of glutenin macropolymer depolymerization to the deterioration of frozen steamed bread dough quality. Food Chemistry, 211:27-33, 2016.

ZAVAREZE, E. D. R.; DIAS, A. R. G. Impact of heatmoisture treatment and annealing in starches: A review. Carbohydrate Polymers, 83:317-328, 2011. 